\title{
Evaluating Contribution of Trees Outside Forests for Income of Rural Livelihoods of Terai Region of Nepal
}

\author{
Yogendra Yadavi,2*, Bir Bahadur Khanal Chhetri ${ }^{3}$, Santosh Raymajhi ${ }^{3}$, Krishna Raj Tiwari ${ }^{3}$, \\ Bishal K. Sitaula ${ }^{4}$
}

${ }^{1}$ Office of the Dean, Institute of Forestry, Tribhuvan University, Pokhara, Nepal

${ }^{2}$ Institute of Forestry, Tribhuvan University, Hetauda Campus, Hetauda, Nepal

${ }^{3}$ Institute of Forestry, Tribhuvan University, Pokhara Campus, Pokhara, Nepal

${ }^{4}$ Norwegian University of Life Sciences, Ås, Norway

Email: *yadavyogendra2003@yahoo.com

How to cite this paper: Yadav, Y., Chhetri, B. B. K., Raymajhi, S., Tiwari, K. R., \& Sitaula, B. K. (2020). Evaluating Contribution of Trees Outside Forests for Income of Rural Livelihoods of Terai Region of Nepal. Open Journal of Forestry, 10, 388-400. https://doi.org/10.4236/ojf.2020.104024

Received: August 7, 2020

Accepted: September 13, 2020

Published: September 16, 2020

Copyright $\odot 2020$ by author(s) and Scientific Research Publishing Inc. This work is licensed under the Creative Commons Attribution International License (CC BY 4.0).

http://creativecommons.org/licenses/by/4.0/

\begin{abstract}
Trees Outside Forests (TOF) is a reliable source of income for farmers in rural area but study regarding this has not been explored in depth yet. Therefore, this study was objectively conducted to assess the contribution of income from TOF products in annual income of rural household. Dhangadimai Municipality of Siraha district, Nepal was selected as study site. Altogether, 300 household surveys and 20 Focus Group Discussions (FGD) were conducted to find the income sources and their contribution including TOF. The descriptive analysis and unitary method were applied to analyze the collected data. The off-farm income was US\$ 1802.57 in total per household. Among it, the highest income was from remittance around US\$ 762.34 (42.29\%) and the lowest from government job around US\$ 166.68 (9.25\%). The farm based total annual income per household was US\$ 685.94 on which, the highest income was US\$220.28 (32.11\%) from grains and the lowest income was US\$ 0.04 from ploughing other farmers' field. The total value of livestock of average household was US\$ 805.99 and out of this, the highest value was of buffalo i.e. US\$ 333.01. At the same time, annual income from TOF product was about US\$853.31 in total per household. Out of this, the highest income was approximately US\$ 521.90 (61.16\%) from fruits followed by US\$ 214.77 (25.17\%) from selling of timber. The highest net income per household was US $\$ 448.66$ respectively from selling timber by rich family while US\$ 233.78 for medium family. In addition, the net income from selling fruit by rich, medium and poor family was US\$ $427.82,550.71$, and 382.43 respectively. Specifically, the total contribution of income only from TOF product was
\end{abstract}


US\$ 853.3027 (20.57\%). This research will be useful document to develop the economic policy related to TOFs in different agroforestry systems.

\section{Keywords}

Farmland, Households, Income, Livelihoods, Trees Outside Forests (TOF)

\section{Introduction}

The role of trees grown outside forests (TOFs) was increasing attention in the world after the mid-1970s. Tree planting initiatives were identified as a potential strategy to meet the forest product needs of growing populations. It also addresses the problems associated to land-management and ecology simultaneously (Foley \& Barnard, 1984; Nair, 1993; Tamale et al., 1995; Arnold, 1997; Long \& Nair, 1999; Bergsten et al., 2014). Trees Outside Forests (TOF) comprise all trees excluded from the definition of forest and other wooded lands (FAO 2001; Bellefontaine et al., 2002). Trees planted outside forests and inside forests share many attributes (Arnold, 1997; McCullough, 1999) but they are not entirely similar. The reason behind this is trees alone do not create forests and trees are not found only in forests (Long \& Nair, 1999). Thus, the private forest land plantations have a significant role to address the alarming rate of deforestation and forest degradation (Arnold, 1997). TOFs are an important natural resource that contributes to the livelihood of people in many regions (Schnell et al., 2015). Additionally, TOFs contribute to economic, environmental and social well-being in areas where there have never been forests or where forests have disappeared (Unasylva, 2000; FAO, 2001; Bellefontaine et al., 2002). The production from planted Eucalyptus species ranges between 20 and $58 \mathrm{~m}^{3} / \mathrm{ha} /$ year and the farmers are able to earn a net profit of INR.50,000 to 150,000 per ha (MoEF, 2009). Tree Farming and the product sale and the related business generated over 177,000 jobs for the local rural people in Bangladesh (Choudhury \& Hossain, 2011) and it was increased to 5.83 million people in 2016 (BFD, 2016).

The forests and trees add diversity and help to sustain the farming system and also uplift the economy of rural households (Nair, 1993; Arnold, 1997; Garforth et al., 1999). Similarly, trees, agriculture, and livestock are interlinked in Nepali farming system and thus sustainability of farming system depends on the continuous existence of tree resources (Gilmour, 1997; Regmi, 1998; Garforth et al., 1999). Moreover, Shrestha (1996) described the changes in the farming system in the Kaski District (e.g., change from free grazing to stall feeding of livestock, labour shortages, and reduced access to natural forest) that have led to increasing tree planting on farmland. Thus, agroforestry has been recognized as one of the important systems for sustaining the rural livelihoods and food security of a large number of rural farmers in the Nepalese hills (Pandit et al., 2014; Catacutan et al., 2017).

The active involvement of the households to plant, protect and utilize the trees 
is the evidence of the increasing tree cover on farmland. There was three-fold increase in the number of trees on farmland over a 24-year period in Sindhuplachok and Kavrepalanchok districts (Carter \& Gilmour, 1989). Similarly, tree cover changes over a 17-year period in the Kavrepalanchok District showed an increase of $31 \%$ to $37 \%$ of tree cover on farmland (Gilmour \& Nurse, 1991). However, there is very limited research related to Trees Outside Forests (TOF) in Siraha district of Terai region, Nepal. In the Sirha district, the forest area was only 4100 ha in the year 2001, which was increased to 4300 ha in year 2010. It showed the increase of forest by $5 \%$ between 2001 and 2010. This is around $4 \%$ forest out of total land in this district but total population is around 637,328. It means there is only 0.03 ha forest per household which indicates the scarcity of the forest resources in Siraha district. Therefore, most of the people in this district depend upon the private forest (Trees Outside Forests) to meet their demand of forest product as well as to generate the income from trading the products. However, there is very limited research related to current status of TOFs on farmland and the ways it contributes to income of rural livelihoods. The main objective of this research was to assess the contribution of income from TOF products in annual income of rural households.

\section{Materials and Methods}

\subsection{Study Area}

The study was carried out in the Siraha district (out of 77 districts of Nepal). The study area covers an area of $42.01 \mathrm{~km}^{2}$. The study site covers Dhangadhi Municipality, Siraha district, Province No.2. This lies between Latitude $26.72^{\circ}$ and $26.80^{\circ}$ North and Longitude $86.34^{\circ}$ and $86.43^{\circ}$ East. The study area is in southern part of Terai region of eastern Nepal (Figure 1). The climate is tropical having average annual temperature of $24.4^{\circ} \mathrm{C}$ and total annual rainfall of $1275 \mathrm{~mm}$. As the forest resources are scarce in this district, World Bank and German

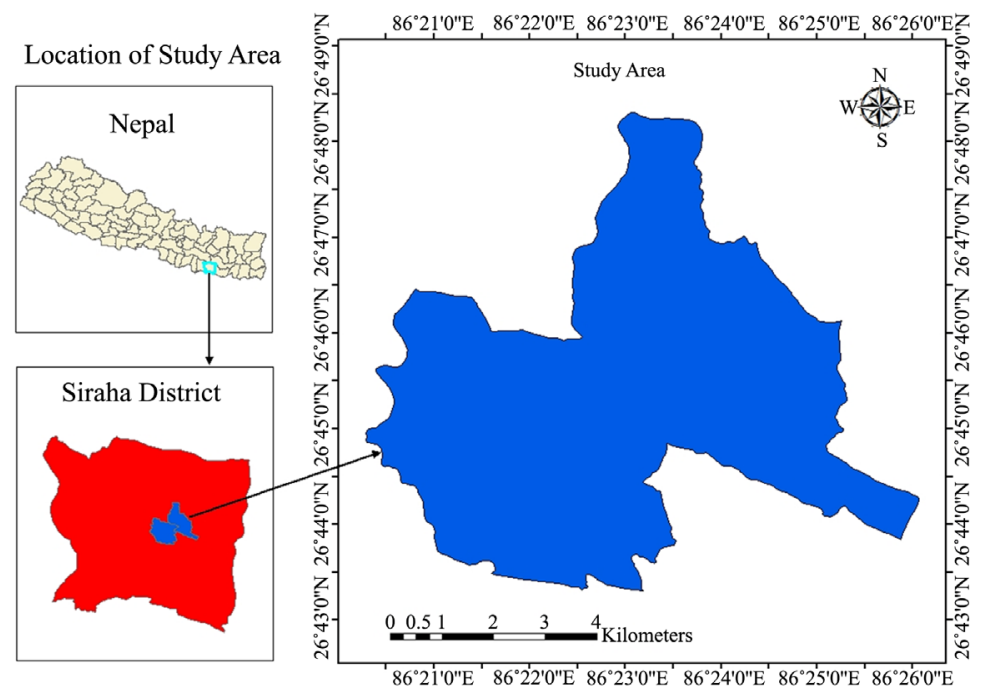

Figure 1. Map of the study area. 
Agency for International Cooperation (GIZ) supported to promote the plantation activities in this district especially private plantation (Evans, 1989; Gautam, 1993). Dalbergia sissoo (Sissoo), Melia azedarach (Bakaino), Albizia spp. (Siris) and Mangifera indica (Mango) are most common planted species in this district (DFO, 2004).

\subsection{Household Selection and Data Collection}

For the study, 300 households (8\%) were randomly selected for interviews out of 3774 total households in the study area. Check list was prepared especially related to livelihood resources (e.g., land-holding, farm, off-farm, livestock and tree) (Chhetri, Larsen, \& Smith-Hall, 2012; Chhetri, Lund, \& Nielsen, 2012).

A total of 20 focus group discussion was organized, specifically 10 events at each site. Then they were organized to categorize the households into rich, medium and poor using their own criteria. A common understanding based on their land holding was reached to divide households into rich ( $\geq 0.5 \mathrm{ha}$ ), medium ( 0.167 ha to $0.5 \mathrm{ha})$, and poor ( $<0.167 \mathrm{ha})$ categorizes (Adams et al., 1997). In-depth, household characteristics, farming system, income, energy, market, legal restrictions, local organizations, credit and extension services and constraints in tree cultivation were collected using a semi-structured questionnaire.

\subsection{Analytical Procedure}

The collected data were analyzed using simple statistics particularly applying the descriptive statistics. In addition, the unitary method was applied to find income from product of TOF (Accastello et al., 2018). The exchange rate of Dollar to Nepali Rupee on $16^{\text {th }}$ February, 2020 was around to NRs. 113.95 for one US\$ Dollar.

\section{Results and Discussion}

Income sources: The income source of households' can mainly be categorized into farm, livestock, off-farm and Trees Outside Forests (TOF). Farm income was generated either from owner-occupied land or land accessed through tenancy. Off-farm income was generated from wage or exchange labour on other farm-based agricultural activities. Non-farm income was generated from other non-agricultural earning (Ellis, 2000). Sources of farm income included cereal crops, livestock and poultry, and sales of vegetables. Sources of off-farm income included wage/labour, remittances and business/trade. The income generated especially from sale of fruit, timber and fuel wood included under the Trees Outside Forests (TOF) income.

The total value of livestock kept by farmers was US\$ 805.99. Out of this, the highest value was US\$ about 333.01 (41.32\%) of buffalo which was followed by US\$ 173.62 (21.54\%) of cow. Similarly, total annual income from non-farm source was US\$ 1802.57. Among this, the highest income was around US\$ 762.34 (42.29\%) from job which was followed by Business with US\$ 453.00 (25.13) (Table $1)$. 
Table 1. Annual value of livestock keeping and annual income from non-farm sources.

\begin{tabular}{cccccc}
\hline \multicolumn{2}{c}{ Total Value of Livestock } & \multicolumn{4}{c}{ Annual Income from Off-Farm Source } \\
\hline Item & Value (US\$/HH) & \% value & Item & Income (US\$/HH) & \% Income \\
\hline Cow & 173.62 & 21.54 & Business & 453.00 & 25.13 \\
Ox & 169.67 & 21.05 & Wage/Labour & 204.69 & 11.36 \\
Buffalo & 333.01 & 41.32 & Job & 166.68 & 9.25 \\
Male Buffalo & 33.39 & 4.14 & Remittance & 762.34 & 42.29 \\
Goat & 88.95 & 11.04 & Others & 215.85 & 11.98 \\
Sheep & 0.44 & 0.05 & 0 & 0 & 0 \\
Chicken & 6.80 & 0.84 & 0 & 0 & 0 \\
Ducks & 0.12 & 0.01 & 0 & 0 & 0 \\
Total & $\mathbf{8 0 5 . 9 9}$ & $\mathbf{1 0 0}$ & Total & $\mathbf{1 8 0 2 . 5 7}$ & 100 \\
\hline
\end{tabular}

The annual net income from farm source and TOF products was varied according to sources and products. Total Annual Net Income from Farm Sources was US\$ 685.94 per households. This was the highest about US\$220.28 (32.11\%) from selling the grains while the lowest record was about US\$0.04 from ploughing. The annual income from TOF product, it was about US\$ 853.31 in total. Among this, the highest income was approximately US\$ 521.90 (61.16\%) from selling the fruits which was followed by US\$214.77 (25.17\%) from selling timber (Table 2).

Table 2 showed the contribution of TOF products from timber was about $25.17 \%$. The timber is one of the major products of TOF. Besides generating the income from timber, they have been using the timber to meet their timber demand to construct the houses, furniture and other purposes because the government forest is very less in this district only 2100 ha which is unable to meet the demand of timber in this district. Therefore, the TOF product is alternative source of timber in the study area.

\subsection{Income from TOF Products According to Rich, Medium and Poor Households}

The annual gross income, costs and net income from Trees Outside Forests (TOF) product per household of rich, medium and poor class people were differed according to products of TOF. The highest gross income, cost and net income per household were US\$ $567.13,118.47$ and 448.66 respectively from selling timber. Similarly, net income from selling timber was US\$233.78 of medium family while it was only US\$ 70.09 of poor family. In addition, the net income from selling fruit by rich, medium and poor family was US\$427.82, 550.71 and 382.43 simultaneously (Table 3).

\subsection{Contribution of Difference Source in Household Income}

Most of the households had diversified income. The major proportion of net 
Table 2. Net Income from farm source and TOF products.

\begin{tabular}{|c|c|c|c|c|c|}
\hline \multicolumn{3}{|c|}{ Annual Net Income From Farm Sources } & \multicolumn{3}{|c|}{ Annual Net Income From TOF Products } \\
\hline Items & Net Income (US\$/HH) & $\%$ income & TOFs Products & Net Income (US\$/HH) & $\%$ income \\
\hline Grains & 220.28 & 32.11 & Timber & 214.77 & 25.17 \\
\hline Vegetables & 115.15 & 16.79 & Fuelwood & 35.45 & 4.15 \\
\hline Agriculture Residue & 13.17 & 1.92 & Fruits & 521.90 & 61.16 \\
\hline Milk & 211.50 & 30.83 & Pole & 7.65 & 0.90 \\
\hline Meat & 29.53 & 4.30 & Fodder & 1.53 & 0.18 \\
\hline Cow Dung & 3.90 & 0.57 & Wild Fruits & 67.43 & 7.90 \\
\hline Ploughing & 0.30 & 0.04 & Wild Vegetables & 3.74 & 0.44 \\
\hline Cash Crops & 32.68 & 4.76 & Bamboo & 0.83 & 0.10 \\
\hline Others & 59.44 & 8.67 & Others (leaves) & 0.01 & 0.00 \\
\hline Total & 685.94 & 100 & Total & 853.31 & 100 \\
\hline
\end{tabular}

Table 3. Gross income, costs and net income of Trees Outside Forests (TOF) products from wealth rank.

\begin{tabular}{|c|c|c|c|c|c|c|c|c|c|}
\hline \multirow[b]{2}{*}{ TOF Products } & \multicolumn{3}{|c|}{ Rich household } & \multicolumn{3}{|c|}{ Medium household } & \multicolumn{3}{|c|}{ Poor household } \\
\hline & $\begin{array}{c}\text { Gross } \\
\text { Income } \\
\text { US } \$ / \mathrm{HH}\end{array}$ & $\begin{array}{c}\text { Cost } \\
\text { US\$/HH }\end{array}$ & $\begin{array}{c}\text { Net } \\
\text { Income } \\
\text { US } \$ / H H\end{array}$ & $\begin{array}{c}\text { Gross } \\
\text { Income } \\
\text { US } \$ / H H\end{array}$ & $\begin{array}{c}\text { Cost } \\
\text { US\$/HH }\end{array}$ & $\begin{array}{c}\text { Net } \\
\text { Income } \\
\text { US\$/HH }\end{array}$ & $\begin{array}{c}\text { Gross } \\
\text { Income } \\
\text { US } \$ / H H\end{array}$ & $\begin{array}{c}\text { Cost } \\
\text { US\$/HH }\end{array}$ & $\begin{array}{c}\text { Net } \\
\text { Income } \\
\text { US } \$ / H H\end{array}$ \\
\hline Timber & 567.13 & 118.47 & 448.66 & 336.07 & 99.94 & 233.78 & 89.63 & 17.95 & 70.09 \\
\hline Fuelwood & 6.58 & 2.19 & 4.39 & 62.20 & 21.02 & 41.43 & 10.92 & 1.46 & 9.46 \\
\hline Fruits & 528.74 & 100.92 & 427.82 & 679.83 & 129.12 & 550.71 & 459.46 & 77.03 & 382.43 \\
\hline Poles & 0.00 & 0.00 & 0.00 & 11.83 & 2.52 & 9.32 & 0.00 & 0.00 & 0.00 \\
\hline Fodder & 0.00 & 0.00 & 0.00 & 1.26 & 0.43 & 1.25 & 3.94 & 0.59 & 3.34 \\
\hline Wild Fruits & 0.00 & 0.00 & 60.33 & 17.37 & 17.37 & 61.47 & 19.70 & 3.51 & 94.19 \\
\hline Wild vegetables & 0.00 & 0.00 & 0.00 & 6.91 & 0.74 & 2.57 & 12.68 & 1.95 & 10.73 \\
\hline Bamboo & 0.00 & 0.00 & 0.00 & 0.50 & 0.18 & 1.01 & 0.00 & 0.00 & 0.00 \\
\hline Total & 1102.46 & 221.59 & 941.20 & 1115.97 & 271.32 & 901.54 & 596.33 & 102.50 & 570.24 \\
\hline
\end{tabular}

income was generated produced by non-farm sources (43.46\%), while an almost equal proportion of income generated from livestock $(19.43 \%)$ and Trees Outside Forests (TOF) (20.57\%) but it was minimum net income from farm products only $16.54 \%$ of total net income. Specifically, this was US\$ 1802.566, 685.9409, 805.9918 and 853.3027 from households per annum from different sources viz. non-farm, farm, livestock and Trees Outside Forests (TOF) respectively (Table 4).

\section{Discussion}

Our studies showed that, Trees Outside Forests (TOF) is an alternative source of timber, firewood, fodder and fruits. At the same time, this is worthy source of income for rural people which contribute substantially to their livelihood. When 
Table 4. Different income sources per HH per annum.

\begin{tabular}{ccc}
\hline Income sources & Net income (US\$) & Percentage \\
\hline Off-farm & 1802.566 & $43.46 \%$ \\
Farm & 685.9409 & $16.54 \%$ \\
Livestock & 805.9918 & $19.43 \%$ \\
TOF products & 853.3027 & $20.57 \%$ \\
\hline
\end{tabular}

there wasn't plenty of forest based resources available nearby, the rural people plant the tree on their private land as a private forest, agro-forest and orchard in order to meet their daily forest product demand and other related products. Realizing this situation, the agroforestry policy (2019) of government of Nepal provides the subsidy to promote the private plantation, agro-forestry as well as the orchard (MoALD, 2019). Studies regarding tree integration on farmland depicted that rural households maintain trees for fuel and other benefits (Nair, 1993; Grimble et al., 1994; Regmi, 2003). Nevertheless, households' on-farm tree management strategies are dynamic and depend on their changing socio-economic activities (Shrestha, 1996; Arnold, 1997).

In rural areas of Nepal, wood collected from natural forests is one of the most critical sources of fuelwood (Christensen et al., 2009). Contribution of fuelwood is about $70 \%$ in total energy supply for the rural population of Nepal (Kandel et al., 2016). Our study showed that most of the rural people have been using the firewood for cooking and heating. The livestock keeping is one of the important professions of the farmers in Terai area. They keep buffalo, cow, goat, chicken, duck and they are generating income from selling these cattle and bird. The highest value was about 333.01 (41.32\%) of buffalo because the people have been keeping these cattle to produce milk in particular. The Yadav communities generally in Terai are like to keep the buffalo most. The contribution of livestock in India is also remarkable in total income (Birthal \& Rao, 2002; Islam et al., 2016). Some studies related to this in Kenya showed that, the livestock keeping is major profession especially for milk and meat production, the value of animal was around nearly one third (31\%) of the total gross value of livestock (Behnke \& Muthami, 2011). This 31\% differs from our study; it may due to the diverse socio-economic and geographical condition between Terai are of Nepal and land of Kenya.

Estimated total annual income from non-farm source was US\$ 1802.57 and the highest income was around US\$ 762.34 (42.29\%) from job. The reason behind this is, most of young people go to golf countries for the employment and some of thhhe people also involve in private and government sector. The study done by Lanjouw \& Shariff (2004) in India showed that, income from non-farm source contributes significantly to total household income. Similar result was found in our study as well. Another study also justified this it was significant contribution to income of Nepali society (Ghimire et al., 2014; Paudel et al., 2017). 
The Trees Outside Forests (TOF) is a very attractive reliable source of income in Nepal and other counties too. In fact, our study showed that annual income was around US\$ 685.94 per households and estimated highest income was about US\$ 220.28 (32.11\%). The main reason behind this may be that farmers are growing different types of plant species such as fruit trees in orchard and forest trees in degraded area. The principle of contribution of Trees Outside Forests (TOF) in total income of the people is justified by several studies. For instance, around $30 \%$ of the total planted area was established in agroforestry systems in China and 49\% in India (Ball et al., 2005; Dogra, 2011), obviously, the products from these TOF contribute in total income. Similar examples are found in plantation establishment for timber, fuelwood to meet the demand of local community in tropical countries (Long \& Nair, 1999). The finding of our study showed that there is significant contribution of TOF in total income of household which is also justified by study done by Regmi (2006).

Baral et al. (2013) stated that contribution of farmland tree (TOFs) was $16.4 \%$ per household per year in the Kanchanpur district in Terai region which falls in the same region of Nepal but our study showed $20.57 \%$ contribution of TOFs. It is quit difference in value, the reason behind this may be due to less percentage of TOF in the western part of Nepal in comparison to eastern part Nepal (Siraha district) (DFRS, 2014).

Many government and non-government agencies have been directly or indirectly involved in households in private plantation especially in Siraha district (Rugendyke, 2007). Most of the medium income households in Nepal have their own agro-forestry system and they have been generating substantial income. The study showed that there was high $(>50 \%)$ proportion of total income from selling of timber and fuelwood from their own private forest. The high income farmers have been generating high income than low income community from private forest (Belcher et al., 2015).

At the same time the income from fodder and fruits are also approximately matching with our research finding. The study done by Pandit et al. (2014) showed that the income from selling the fruit was US\$ 57.05 in Kavreplanchok. This income is less in comparison to finding of our research; the differences in income may be due to difference in study site, price of fruit and year.

\section{Conclusion and Recommendation}

The integration of trees on farmland significantly contributes in total income of rural livelihood. Among the total income of household, the highest income was from remittance but it was the lowest from government job. More specifically, out of total farm based annual income per household, the highest income was from grains while the lowest income was from ploughing other farmers' field. Out of total value of livestock, the highest value was of buffalo. Besides, annual income from TOF product was a remarkable one and among this, the highest income was from fruits and it was followed by selling timber. The highest net 
income per household was from selling fruits and timber by rich family but it was the lowest by poor family. Specifically, the total contribution of income only from TOF product was about one fifth of total income. This research will be useful document to develop the economic policy related to TOFs in different agroforestry systems.

Thus, it is recommended that the contribution of TOF and other products shall be recognized as household income sources of rural farmers. Similarly, the contribution of income from different sources should be intensively carried out and in depth studies are essential. Such study should be carried out to other parts of Nepal covering challenging issues of income generation from TOF and others as well.

\section{Acknowledgements}

The authors gratefully acknowledge the editors and anonymous reviewers for their critical comments and suggestions. We would like to acknowledge the NORHED project Institute of Forestry (IOF), Dean Office Pokhara for the financial support.

\section{Data Availability}

The data used in this paper came from socioeconomic status of wealth rank (Rich, Medium and Poor) of study area in Terai region of Nepal. Of the total sampled Households sample data were used in the analysis. If required, raw dataset can be made available.

\section{Conflicts of Interest}

The authors declare that they have no conflicts of interest.

\section{References}

Accastello, C., Blanc, S., Mosso, A., \& Brun, F. (2018). Assessing the Timber Value: A Case Study in the Italian Alps. Forest Policy and Economics, 93, 36-44. https://doi.org/10.1016/j.forpol.2018.05.010

Adams, A. M., Evans, T. G., Mohammed, R., \& Farnsworth, J. (1997). Socioeconomic Stratification by Wealth Ranking: Is It Valid? World Development, 25, 1165-1172. https://doi.org/10.1016/S0305-750X(97)00024-7

Arnold, J. E. M. (1997). Framing the Issues. In J. E. M. Arnold, \& P. A. Dewees (Eds.), Farms, Trees and Farmers: Responses to Agricultural Intensification (pp. 1-17). London: Earthscan.

https://scholar.google.com/scholar?hl=en\&as_sdt=0\%2C5\&q=Arnold\%2C+J.+E.+M.+ $\% 281997 \% 29$

Ball, J., Carle, J., \& Del Lungo, A. (2005). Contribution of Poplars and Willows to Sustainable Forestry and Rural Development. Unasylva 221, 56, 3-9. http://www.fao.org/tempref/docrep/fao/008/a0026e/a0026e03.pdf

Baral, S. K., Malla, R., Khanal, S., \& Shakya, R. (2013). Trees on Farms: Diversity, Carbon Pool and Contribution to Rural Livelihoods in Kanchanpur District of Nepal. BankoJanakari, 23, 3-11. https://doi.org/10.3126/banko.v23i1.9462 
Behnke, R. H., \& Muthami, D. (2011). The Contribution of Livestock to the Kenyan Economy.

https://cgspace.cgiar.org/bitstream/handle/10568/24972/IGAD_LPI_WP_03-11.pdf?se quence $=1$

Belcher, B., Achdiawan, R., \& Dewi, S. (2015). Forest-Based Livelihoods Strategies Conditioned by Market Remoteness and Forest Proximity in Jharkhand, India. World Development, 66, 269-279. https://doi.org/10.1016/j.worlddev.2014.08.023

Bellefontaine, R., Petit, S., PainOrcet, M., Deleporte, P., \& Bertault, J. (2002). Trees Outside Forests: Towards a Better Awareness. Rome: Food and Agriculture Organisation of the United Nations. https://www.cabdirect.org/cabdirect/abstract/20046798932

Bergsten, A., Galafassi, D., \& Bodin, Ö. (2014). The Problem of Spatial Fit in Social-Ecological Systems: Detecting Mismatches between Ecological Connectivity and Land Management in an Urban Region. Ecology and Society, 19, 6.

https://doi.org/10.5751/ES-06931-190406

BFD (2016). Climate Resilient Participatory Afforestation and Reforestation Project Updating Forestry Master Plan for Bangladesh (2017-2036).

http://pubdocs.worldbank.org/en/848671521827530395/FMP-Full-report-final.pdf

Birthal, P. S., \& Rao, P. P. (2002). Economic Contributions of the Livestock Subsector in India. In Technology Options for Sustainable Livestock Production in India (p. 12). New Delhi: ICRISAT-Patancheru.

http://agropedialabs.iitk.ac.in/openaccess/sites/default/files/CO\%200027_0.pdf\#page=2 0

Carter, A. S., \& Gilmour, D. A. (1989). Increase in Tree Cover on Private Farm Land in Central Nepal. Mountain Research and Development, 9, 381-391.

https://www.jstor.org/stable/3673586

https://doi.org/10.2307/3673586

Catacutan, D. C., Van Noordwijk, M., Nguyen, T. H., Öborn, I., \& Mercado, A. R. (2017). Agroforestry: Contribution to Food Security and Climate-Change Adaptation and Mitigation in Southeast Asia. White Paper, Bogor: World Agroforestry Centre (ICRAF) Southeast Asia Regional Program.

http://www.worldagroforestry.org/publication/agroforestry-contribution-food-security -and-climate-change-adaptation-and-mitigation

Chhetri, B. B. K., Larsen, H. O., \& Smith-Hall, C. (2012). Law Enforcement in Community Forestry: Consequences for the Poor. Small Scale Forestry, 11, 435-452.

https://link.springer.com/article/10.1007/s11842-011-9194-7

https://doi.org/10.1007/s11842-011-9194-7

Chhetri, B. B. K., Lund, J. F., \& Nielsen, Ø. J. (2012). The Public Finance Potential of Community Forestry in Nepal. Ecological Economics, 73, 113-121.

https://doi.org/10.1016/j.ecolecon.2011.09.023

Choudhury, J. K., \& HossainMd, A. A. (2011). Bangladesh Forestry Outlook Study. Bangkok: Food and Agriculture Organization of the United Nations Regional Office for Asia and the Pacific. http://www.fao.org/3/a-am628e.pdf

Christensen, M., Rayamajhi, S., \& Meilby, H. (2009). Balancing Fuelwood and Biodiversity Concerns in Rural Nepal. Ecological Modelling, 220, 522-532.

https://doi.org/10.1016/j.ecolmodel.2008.10.014

DFO (2004). Private Forest Monitoring and Evaluation Report (2004/2005). Siraha: District Forest Office.

DFRS (2014). Terai Forests of Nepal (2010-2012). Forest Resource Assessment Nepal Project, Department of Forest Research and Survey. 
https://scholar.google.com/scholar_lookup?title=Terai\%20Forests\%20of\%20Nepal\%20 (2010-2012)\&author=FRA\%2FDFRS\&publication_year=2014

Dogra, A. S. (2011). Contribution of Trees Outside Forests toward Wood Production and Environmental Amelioration. Indian Journal of Ecology, 38, 1-5.

https://scholar.google.com/scholar?hl=en\&as_sdt=0\%2C5\&q=Dogra\%2C+A.+S.+\%282 011\%29.+Contribution+of+trees+outside+forests+toward+wood+production+and+en vironmental+amelioration.+Indian +J.+Ecol\%2C+38\%2C+1-5.\&btnG

Ellis, F. (2000). Rural Livelihoods and Diversity in Developing Countries. Oxford: Oxford University Press.

https://books.google.com.np/books?hl=en\&lr=\&id=gCKQs-3NKhUC\&oi=fnd\&pg=PR9 $\& \mathrm{dq}=$ Ellis, + F.+(2000).Rural+livelihoods+and+diversity+in+developing+countries.+Oxf ord+University + Press, + Oxford\&ots $=$ vWWddoktif\&sig $=32 \mathrm{GgNNiuNlDkd17o24fveLfKt}$ Lk\&redir_esc=y\#v=onepage\&q=Ellis\%2C\%20F.\%20(2000).Rural\%20livelihoods\%20and \%20diversity\%20in\%20developing\%20countries.\%20Oxford\%20University\%20Press\%2 C\%20Oxford \&f=false

Evans, P. T. (1989). Technical Assistance to the Terai Forestry Project (UTF/NEP/ 038/NEP): Community Forestry Private Planting/Farm Forestry Survey. Kathmandu: Terai Community Forestry Development Project/Food and Agriculture Organization of the United Nations.

FAO (2001). Global Forest Resources Assessment 2000. Main Report, FAO Forestry Paper 140, Rome: Food and Agriculture Organisation of the United Nations. http://www.fao.org/3/i1757e/i1757e.pdf

Foley, G., \& Barnard, G. (1984). Farm and Community Forestry. London: International Institute for Environment and Development.

Garforth, C. J., Malla, Y. B., Neopane, R. P., \& Pandit, B. H. (1999). Socioeconomic Factors and Agroforestry Improvements in the Hills of Nepal. Mountain Research and Development, 19, 273-278. https://www.jstor.org/stable/25164033

Gautam, K. H. (1993). Changing Farm Landscape: A Village Perspectives of Nepal's Inner Terai. BankoJanakari, 4, 112-117.

Ghimire, R., Huang, W. C., \& Shrestha, R. B. (2014). Factors Affecting Nonfarm Income Diversification among Rural Farm Households in Central Nepal.

https://scholar.google.com/scholar?hl=en\&as_sdt=0\%2C5\&q=Ghimire\%2C+R.\%2C+HUA NG\%2C+W.+C.\%2C+\%26Shrestha\%2C+R.+B.+\%282014\%29.Factors+affecting+nonfarm +income+diversification+among+rural+farm+households+in+central+Nepal.https $\% 3 \mathrm{~A} \% 2$ F\%2Fwww.sid.ir\%2Fen\%2Fjournal\%2FViewPaper.aspx\%3Fid\%3D377197\&btnG=

Gilmour, D. A. (1997). Rearranging Trees in the Landscape in the Middle Hills of Nepal. In J. E. M. Arnold, \& P. A. Dewees (Eds.), Farms, Trees and Farmers: Responses to Agricultural Intensification (pp. 21-42). London: Earthscan.

https://books.google.com.np/books?hl=en\&lr=\&id=ViuiAwAAQBAJ\&oi=fnd\&pg=PA $21 \& \mathrm{dq}=$ Gilmour, + D. + A. $+(1997)$. Rearranging + trees + in + the + land + scape + in + the + mid dle+hills+of+Nepal.+In:+Arnold+JEM,+Dewees+PA+(eds)+Farms,+trees+and+farme rs:+responses+to+agricultural+intensification.+Earthscan, + London, $+\mathrm{pp}+21-42 \&$ ots $=\mathrm{Z}$ 0Nqj5pp8x\&sig=VG7du4XcgvA3X3RF1f254YaQlvA\&redir_esc $=\mathrm{y} \# \mathrm{v}=$ onepage\&q\&f=fa lse

Gilmour, D. A., \& Nurse, M. C. (1991). Farmer Initiatives in Increasing Tree Cover in Central Nepal. In N. C. Saxena, \& V. Ballabh (Eds.), Farm Forestry in South Asia (pp. 87-103). New Delhi: Sage. https://www.jstor.org/stable/3673716

Grimble, R. J., Aglionby, J., \& Quant, J. (1994). Tree Resources and Environmental Policy: A Stakeholder Approach. NRI Socio-Economic Series 7, Chatham: Natural Resources Institute. http://gala.gre.ac.uk/id/eprint/12002 
Islam, M. M., Anjum, S., Modi, R. J., \& Wadhwani, K. N. (2016). Scenario of Livestock and Poultry in India and Their Contribution to National Economy. International Journal of Science, Environment and Technology, 5, 956-965. http://www.ijset.net/journal/956.pdf

Kandel, P., Chapagain, P. S., Sharma, L. N., \& Vetaas, O. R. (2016). Consumption Patterns of Fuelwood in Rural Households of Dolakha District, Nepal: Reflections from Community Forest User Groups. Small-Scale Forestry, 15, 481-495.

https://doi.org/10.1007/s11842-016-9335-0

Lanjouw, P., \& Shariff, A. (2004). Rural Non-Farm Employment in India: Access, Incomes and Poverty Impact. Economic and Political Weekly, 39, 4429-4446. https://www.jstor.org/stable/4415616

Long, A. J., \& Nair, R. (1999). Trees Outside Forests: Agro-, Community and Urban Forestry. New Forests, 17, 145-174. https://doi.org/10.1023/A:1006523425548

McCullough, R. B. (1999). Four Common Myths about Plantation Forestry. New Forests, 17, 111-118. https://doi.org/10.1007/978-94-017-2689-4_9

MoALD (2019). National Agro-Forestry Policy, 2019. Kathmandu: Ministry of Agriculture and Livestock Development, Government of Nepal Singhadurbar.

MoEF (2009). India Forestry Outlook Study Food and Agriculture Organization of the United Nations Regional Office for Asia and the Pacific. India: Ministry of Environment and Forest. http://www.fao.org/3/am251e/am251e00.pdf

Nair, P. K. R. (1993). An Introduction to Agroforestry. Dordrecht: Kluwer.

https://books.google.com.np/books?hl=en\&lr=\&id=CkVSeRpmIx8C\&oi=fnd\&pg=PR1 $1 \&$ dq=Nair, + P.+K.+R.+(1993).An+introduction + to+agroforestry.+Kluwer, + Dordrech t\&ots=YYO2DaIGvl\&sig=J5Pq3KlBag4bRVurI_jrceivUYw\&redir_esc=y\#v=onepage\& q=Nair\%2C\%20P.\%20K.\%20R.\%20(1993).An\%20introduction\%20to\%20agroforestry. $\% 20$ Kluwer\%2C\%20Dordrecht $\& \mathrm{f}=$ false https://doi.org/10.1007/978-94-011-1608-4

Pandit, B. H., Shrestha, K. K., \& Bhattarai, S. S. (2014). Sustainable Local Livelihoods through Enhancing Agroforestry Systems in Nepal. Journal of Forest and Livelihood, 12, 47-63.

https://www.forestaction.org/app/webroot/vendor/tinymce/editor/plugins/filemanager /files/JFL\%20VOl\%2012\%20\%281\%29/Pandit\%20et\%20al.pdf

Paudel Khatiwada, S., Deng, W., Paudel, B., Khatiwada, J. R., Zhang, J., \& Su, Y. (2017). Household Livelihood Strategies and Implication for Poverty Reduction in Rural Areas of Central Nepal. Sustainability, 9, 612. https://doi.org/10.3390/su9040612

Regmi, B. N. (1998). Program Dynamics of the Nepal Agroforestry Foundation in Majhitar of Dhading District, Nepal. Unpublished MSc. Thesis, Laguna: Graduate School, Department of Social Forestry, University of the Philippines Los Baños. https://agris.fao.org/agris-search/search.do?recordID=PH1998100681

Regmi, B. N. (2003). Contribution of Agroforestry for Rural Livelihoods: A Case of Dhading District, Nepal. The International Conference on Rural Livelihoods, Forests and Biodiversity, Bonn, 19-23 May 2003.

https://www.cifor.org/publications/corporate/cd-roms/bonn-proc/pdfs/papers/T3_FIN AL_Regmi.pdf

Regmi, B. N. (2006). Problems and Prospects of Tree Integration on Farm for Rural Livelihoods: A Study of Siraha District, Nepal. Unpublished PhD Thesis, Reading: University of Reading. http://ethos.bl.uk/OrderDetails.do?uin=uk.bl.ethos.433450

Rugendyke, B. (2007). Lilliputians or Leviathans? NGOs as Advocates. In B. Rugendyke 
(Ed.), NGOs as Advocates for Development in a Globalising World (pp. 1-16). London: Routledge. https://hdl.handle.net/1959.11/2568 https://doi.org/10.4324/9780203939215

Schnell, S., Kleinn, C., \& Ståhl, G. (2015). Monitoring Trees Outside Forests: A Review. Environmental Monitoring and Assessment, 187, 600. https://doi.org/10.1007/s10661-015-4817-7

Shrestha, R. B. (1996). Trees: Farmers' Response to Change. LEIA Newsletter, 12, 20-21. https://scholar.google.com/scholar?hl=en\&as_sdt=0\%2C5\&q=Shrestha\%2C+R.B.+\%28 $1996 \% 29 .+$ Trees\%3A+farmers'+response+to+change.+ILEIA+News+Lett+12\%281\%2 9\%3A20-21\&btnG

Tamale, E., Jones, N., \& Riddihough, I. P. (1995). Technologies Related to Participatory Forestry in Tropical and Sub-Tropical Countries. Technical Paper Number 299, Washington DC: The World Bank. https://doi.org/10.1596/0-8213-3399-2

Unasylva (2000). Trees Outside Forests: Editorial. Unasylva, 200, 3-10. http://www.fao.org/3/a-i4447e.pdf 